\title{
New records of Zygaenidae (Lepidoptera) from Montenegro
}

\author{
Predrag Jakšići , Ana Nahirnić-Beshkova²
}

\author{
(1) Čingrijina 14/25, Zvezdara, 11000 Belgrade, Serbia, \\ jaksicpredrag@gmail.com; https://orcid.org/0000-0002-2604-9449 \\ (2) National Museum of Natural History, Bulgarian Academy of Sciences, 1 Tsar Osvoboditel Blvd, 1000 Sofia, \\ Bulgaria, ana.diaphana@gmail.com; https://orcid.org/0000-0002-7922-9910
}

\begin{abstract}
Four areas in Montenegro were visited at the end of June - beginning of July 2020. We found 12 species of Zygaenidae. Second records for Adscita statices drenowskii (Alberti, 1939) and Jordanita globulariae (Hübner, 1793) for Montenegro are provided here. Additional records are given for J. notata (Zeller, 1847) and Zygaena punctum Ochsenheimer, 1808 for which there are less than ten localities known in Montenegro.
\end{abstract}

Keywords: faunistics, Montenegro, Procridinae, Zygaeninae

\section{Introduction}

Montenegro and Albania are the least studied Balkan countries considering Zygaenidae (Nahirnić, 2018). In the last ten years, four species were reported for the first time in Montenegro: Zygaena bizae (Esper, 1800), Z. minos ([Denis \& Schiffermüller], 1775), Z. cynarae (Esper, 1789), and Z. transalpina (Esper, 1780) (Nahirnić et al., 2011; Nahirnić et al., 2013; Nahirnić \& Tarmann, 2014) increasing the total number of species occurring in the country to 23 . In addition, a few other species are expected, such as Theresimima ampellophaga (Bayle-Barelle, 1808), Rhagades pruni ([Denis \& Schiffermüller], 1775), Adscita albanica (Naufock, 1926), and Jordanita graeca (Jordan, 1907). Published data for many species, even those common in the wider region, are scarce; for some species of Procridinae data are not reliable because genitalia examination has not been done. Most of the attention was given to coastal areas, Mt Durmitor, the Tara River Canyon and their adjacent areas. Despite its small size, vast areas of the country lack any data on Zygaenidae. Here we present data for ar- eas where there are no data or just single records, with the exception of Mt Lovćen. However, our records from Lovćen are from the main ridge, where Zygaenidae were not reported before.

We explored 18 localities in four areas: Vrulja in North Montenegro, Mt Orjen and Grahovsko Polje, Mt Lovćen and Mt Visitor. The field work was conducted from 28.VI.2020 to 9.VII.2020 by Predrag Jakšić. List of the localities and dates (in chronological order):

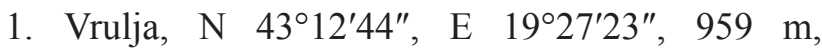
28.VI.2020

2. Grahovsko Polje, Gradine, N 42³9'06", E $18^{\circ} 36^{\prime} 10^{\prime \prime}, 975 \mathrm{~m}, 28$.VI.2020

3. Orjen, Bijela Gora, N 42 $38^{\prime} 04^{\prime \prime}$, E 18 $34^{\prime} 07^{\prime \prime}$, $1240 \mathrm{~m}, 28$. VI.2020

4. Orjen, Vrbanje Village, N 42 $32^{\prime} 45^{\prime \prime}$, E $18^{\circ} 30^{\prime} 38^{\prime \prime}$, 1124 m, 29.VI.2020

5. Orjen, Vrbanje Village SE, Prodoli, N 42 $32^{\prime} 11^{\prime \prime}$, E 18³1'13", 1124 m, 29.VI.2020

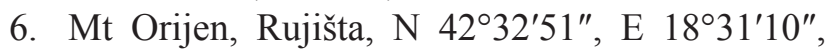
1137 m, 29.VI.2020 
7. Mt Orijen, Kape, N 42³3'51", E 18²9'47", 976 m, 29.VI. 2020

8. Mt Orijen, Subra, N 42³0'46", E 18³3'16", 1177 $\mathrm{m}, 30$. VI. 2020

9. Mt Lovćen, Ivanova Korita, N 42 $22^{\prime} 46^{\prime \prime}$, E $18^{\circ} 49^{\prime} 53^{\prime \prime}, 1280 \mathrm{~m}, 2$.VII. 2020

10. Mt Lovćen, Štirovnik Summit foothill, Međuvršje, N 42²4'06", E 1849'31", 1370 m, 2.VII.2020

11. Mt Lovćen, Ugnji W-SW, below Veliki Silje-

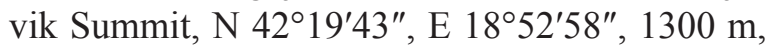
3.VII. 2020

12. Lovćen, Majstori SE, below Maini Vrh Summit, N 42 $19^{\prime} 56^{\prime \prime}$, E $18^{\circ} 52^{\prime} 03^{\prime \prime}, 1202$ m, 3.VII.2020

13. Mt Lovćen, Ivanova Korita, Treštenski Vrh foothill, N 42²2'26", E 18 50'51", $1316 \mathrm{~m}$, 4.VII. 2020

14. Lovćen, Majstori NNW, N 42 $21^{\prime} 41^{\prime \prime}, \mathrm{E}$ $18^{\circ} 50^{\prime} 43^{\prime \prime}, 1330 \mathrm{~m}, 4$. VII. 2020

15. Mt Lovćen, Treštenski Vrh, N 42²2'19", E $18^{\circ} 50^{\prime} 51^{\prime \prime}, 1469 \mathrm{~m}, 5$.VII. 2020

16. Mt Visitor, Zaparenik Katun, N 42 $38^{\prime} 32^{\prime \prime}$, E $19^{\circ} 54^{\prime} 12^{\prime \prime}, 1183 \mathrm{~m}, 8$.VII.2020.

17. Mt Visitor, Jagnjičar, N 42³7'35", E 1953'12", $1820 \mathrm{~m}, 8$. VII. 2020.

18. Mt Visitor, Kruševo, N 4240'14", E 1951'54", $890 \mathrm{~m}$, 9.VII.2020

\section{Methods}

Procridinae and Zygaena purpuralis were determined by the examination of genitalia. Dissection of genitalia was done according to Robinson (1975). All genitalia were preserved in micro vials filled with glycerol with the exception of genitalia of one male specimen of Adscita statices statices (Linnaeus, 1758) x A. statices drenowskii (Alberti, 1939), which was mounted in Euparal on a slide. Photo of the genitalia slide was taken using Nikon Camera with AF-S Micro Nikkor Lens. The material is deposited in the collection of the first author.

\section{Results and discussion}

We recorded a total of twelve species: four of Procridinae and eight of Zygaeninae. In the list of the species below, each species is followed by the numbers of localities and comments on its occurrence in Montenegro.

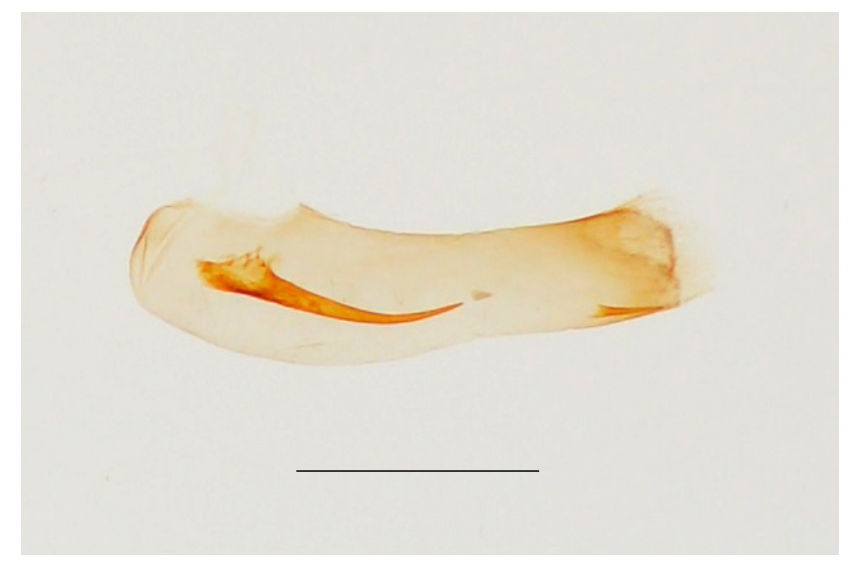

Fig. 1. Aedeagus of Adscita statices statices (Linnaeus, 1758) x Adscita statices drenowskii (Alberti, 1939) hybrid, Grahovsko Polje, Gradine, 28.VI.2020. Scale $=1 \mathrm{~mm}$.

Procridinae

- Adscita statices statices (Linnaeus, 1758): 2, 13, 14. Adscita statices statices $\mathrm{x}$ A. statices drenowskii (Alberti, 1939): 2. Dissection of genitalia is necessary for the proper determination of A. statices. The two subspecies $A$. statices statices and $A$. statices drenowskii differ in the largest cornutus of the aedeagus. In the aforementioned subspecies cornutus is curved, while in the lattercornutus is straight. Intermediate forms show curviness of cornutus of different degree. Drawings are given in Tarmann (1979) and Jakšić (1990). This is the first photo of genitalia of a male hybrid (Fig. 1, ANZ 781). Here we emphasis the importance of exploring cornutus of $A$. statices. A. statices drenowskii is distributed on the Southern Balkans and the hybridisation belt goes from eastern, central, southern and western Serbia, northern Montenegro, northeastern Albanian and northwestern North Macedonia. Our record in Grahovsko Polje is a continuation of the northern border of its distribution and it is the westernmost record of A. statices drenowskii. In Montenegro, a hybrid was found only once at Čeline at the Crno Jezero on Mt Durmitor (Jakšić, 1990). There are no other records on A. statices drenowskii in the country. In fact, there are no records of $A$. statices in almost the whole southern part of Montenegro.

- Adscita mannii (Lederer, 1853): 10, 18. We consider almost all published records for Montenegro (Rebel, 1913, 1917; Rebel \& Zerny, 1931; Vasić et 
al., 1990) as not reliable, since voucher specimens have not been found in respective collections and genitalia have most probably not been checked. Only Jakšić et al. (2019) provided two reliable records. A. mannii is a widespread species on the Balkans and more records should be expected in Montenegro. It can be confused with several species of Adscita, thus every reliable record, based on genitalia dissection, is valuable.

- Jordanita notata (Zeller, 1847): 2, 10, 12. Up to date, four records are known from Montenegro: two from Mt Durmitor and two from near Podgorica (Jakšić, 1990; Jakšić et al., 2019). Our three additional records are located in new areas.

- Jordanita globulariae (Hübner, 1793): 18. The only published record for $J$. globulariae for Montenegro is from the Lijeva Reka (Veruša) (Sijarić, 1991). Kruševo on Mt Visitor is the second record of this species in the country. $J$. globulariae is not rare in the surrounding countries and, therefore, we expect this species to be recorded relatively frequently in Montenegro as research on Zygaenidae intensifies.

\section{Zygaeninae}

- Zygaena purpuralis (Brünnich, 1763): 3, 10, 12, 17. In Montenegro two species of $Z$. purpuralis complex occur: Z. purpuralis and Z. minos ([Denis \& Schiffermüller], 1775). These species can be distinguished only on the basis of genitalia or larvae (Nahirnić, 2019). Z. purpuralis is known to occur at 16 localities in Montenegro based on reliable and precise records published in Naumann et al. (1983), Jakšić (1990, 2003), Nahirnić et al. (2011b) and Jakšić et al. (2019). Our new data originate from the areas where it has not been found before. Other papers that mention Z. purpuralis exist but determination has not been based on the examination of genitalia. Every reliable record based on dissection is valuable and will contribute to the knowledge on distribution of both $Z$. purpuralis and Z. minos in Montenegro.

- Zygaena punctum Ochsenheimer, 1808: 10, 14. It has been reported from less than ten localities in Montenegro, mostly in the southern part of the country. It is a xerothermophilous species feeding on Eryngium spp., of which E. campestre L. is a common species in Montenegro. Its suitable habi- tats are well-represented in the coastal lowlands and mountains and we expect it to be a common species there. Previously, it has been found at two localities on Mt Lovćen. Here we add two more localities from Mt Lovćen.

- Zygaena carniolica (Scopoli, 1763): 3, 4, 6, 7, 8, $9,10,11,12$. In comparison with the surrounding countries, $Z$. carniolica is not a widespread species in Montenegro. This is certainly the result of lack of research.

- Zygaena viciae ([Denis \& Schiffermüller], 1775): 11,18 . These are the first data of $Z$. viciae in the southern and the eastern Montenegro.

- Zygaena loti ([Denis \& Schiffermüller], 1775): 3, 11. In comparison with the surrounding countries, $Z$. loti is not a widespread species in Montenegro. This is certainly the result of lack of research.

- Zygaena angelicae Ochsenheimer, 1808: 10, 11, 16. In comparison with the surrounding countries, $Z$. angelicae is not a widespread species in Montenegro. This is certainly the result of lack of research.

- Zygaena filipendulae (Linnaeus, 1758): 1, 3, 5, $11,12,15$. Even $Z$. filipendulae, the most common and widespread species in the region, is not distributed throughout the country. This is certainly the result of lack of research.

- Zygaena lonicerae (Scheven, 1777): 2, 9, 10, 11, $12,13,15$. Common and widespread species in the region but not widespread in Montenegro. This is certainly the result of lack of research. Our record from the Grahovsko Polje fills the distributional gap in the area of southern Bosnia and Herzegovina and western Montenegro.

\section{References}

Jakšić P. 1990 Zygaenoidea (Insecta, Lepidoptera). In: Nonveiller G. (ed.) Fauna Durmitora 3. Posebna izdanja knjiga 23. Crnogorska akademija nauka i umjetnosti, Titograd, 203-232.

Jakšić P. 2003 Fauna leptira (Lepidoptera: Zygaenidae, Hesperioidea i Papilionoidea). In: Amidžić L., Janković M.M., Jakšić P. (eds) Prokletije of Metohia, the natural and cultural heritage. Institute for Nature Conservation of Serbia, Belgrade, 234-261.

Jakšić P., Tarmann G.M., Nahirnić A. 2019 Further notes on Zygaenidae (Lepidoptera) from Monte- 
negro. Biologica Nyssana 10 (1): 43-48. https:// doi.org/10.5281/zenodo.3464006

Nahirnić A. 2018 A review of research on Zygaenidae of the Balkan Peninsula and the Greek Islands. Abstracts of the XVI. International Symposium Zygaenidae, İzmir, Turkey, 1-5 May 2018, 2.

Nahirnić A. 2019 Zygaena diaphana Staudinger, 1887 bona species (Lepidoptera: Zygaenidae). SHILAP Revista de lepidopterología 47 (186): 341-347.

Nahirnić A., Jakšić P., Tarmann G.M. 2011 Notes on Zygaena Fabricius, 1775, from the Balkan Peninsula (Insecta, Lepidoptera, Zygaenidae). Acta Entomologica Slovenica 19 (2): 145-154.

Nahirnić A., Tarmann G.M. 2014 Zygaena brizae (Esper, 1800), a new species for Montenegro (Lepidoptera: Zygaenidae). Acta entomologica serbica $19(1 / 2)$ : 79-82.

Nahirnić A., Tarmann G.M., Jakšić P. 2011 A review of faunistical data on Zygaenidae (Lepidoptera) in the central-western Balkan peninsula. In: Bulić Z. (ed.) International Conference, Nature Protection in XXI century, Proceedings of the conference, Thematic sessions, abstracts, poster presentations. Book No 2: 451-455.

Nahirnić A., Tarmann G.M., Jakšić P. 2013 New data on rare Zygaenidae from the Balkan Peninsula. XVIII European Congress of Lepidopterology, Programme and Abstracts, 29 July - 4 August 2013, Blagoevgrad, Bulgaria, 58.

Naumann C.M., Richter G., Weber U. 1983 Spezifität und Variabilität im Zygaena-purpuralis-Komplex (Lepidoptera, Zygaenidae). Theses Zoologicae 2: $1-263$.

Rebel H. 1913 Studien über die Lepidopterenfauna der Balkanländer. III. Teil. Sammelergebnisse aus Montenegro, Albanien, Mazedonien und Thrazien. Annalen des Naturhistorischen Hofmuseums in Wien 27: 281-334.
Rebel H. 1917 Lepidopteren aus Neumontenegro (Ergebnisse der im Jahre 1916 im Auftrage und auf Kosten der Kaiserl. Akademie der Wiss. in Wien von Dr. Arnold Penther ausgeführten zoologischen Forschungsreise in Serbien und Neumontenegro). Sitzungsberichte der Kaiserliche Akademie der Wissenschaften in Wien, Mathematisch-naturwissenschaftliche Klasse 126 (1): 765-813.

Rebel H., Zerny H. 1931 Die Lepidopterenfauna Albaniens (mit Berücksichtigung der Nachbargebiete). Denkschriften der Akademie der Wissenschaften in Wien, Mathematisch-Naturwissenschaftliche Klasse 103: 37-161.

Robinson G. 1976 The preparation of slides of Lepidoptera genitalia with special reference to the Microlepidoptera. Entomologist's Gazette 27: 127-132.

Sijarić R. 1991 A catalogue of the Lepidoptera (Insecta) Collection of the Sarajevo donor - Boro Mihljević. Glasnik Zemaljskog muzeja Bosne i Hercegovine PN (NS) 30: 169-360.

Tarmann G.M. 1979 Die statices-Gruppe des Genus Procris F. Mitteilungen der Münchner Entomologischen Gesellschaft 68: 45-108.

Vasić K., Tomić D., Carnelutti J., Zečević M., Kranjčev R. 1990 Heterocera I. Bombyces et Sphinges (Insecta, Lepidoptera). In: Nonveiller G. (ed.) Fauna Durmitora 3. Posebna izdanja knjiga 23. Crnogorska akademija nauka i umjetnosti, Titograd, 99-157. 